\title{
Efforts to Build a Culture of Transformational Leadership in Islamic Education Institutions
}

\author{
Zaenal Arifin ${ }^{1}$, Binti Maunah ${ }^{2}$ \\ ${ }^{1}$ Institut Agama Islam Tribakti Kediri, ${ }^{2}$ Institut Agama Islam Negeri Tulungagung \\ 12zae.may13@gmail.com, ${ }^{2}$ uun.lilanur@gmail.com
}

\begin{abstract}
This article aimed to explain how to civilized transformational leadership in Islamic educational institutions. Discussions about transformational leadership have recently become lively to be discussed at the Islamic Education Institution (LPI). This is because Islamic educational institutions have prophetic religious spirits that are considered appropriate to be developed at LPI. Bernard Bass's transformational leadership theory becomes the main theoretical framework. The characteristics and goals of transformational leadership are in line with the conception of prophetic leadership in Islam. Therefore, to cultivate transformative leadership in LPI, it needs to be preceded by the creation of an organizational culture that implements prophetic values. Then to realize it can use three civilizing models, namely; structural models, formal models and mechanical models.
\end{abstract}

Keywords: Culture Building, Prophetic Leadership, Transformative Leadership

\begin{abstract}
Abstrak
Penulisan artikel ini ditujukan untuk menjelaskan bagaimana membudayakan kepemimpinan transformasional di lembaga pendidikan Islam. Diskusi tentang kepemimpinan transformasional akhir-akhir ini menjadi marak diperbincangkan untuk diaplikasikan di Lembaga Pendidikan Islam (LPI). Hal ini karena lembaga pendidikan Islam memiliki ruh religius profetik yang dianggap tepat untuk dikembangkan di LPI. Teori kepemimpinan transformasional Bernard Bass menjadi kerangka teori utamanya. Karakteristik dan tujuan kepemimpinan transformasional sejalan dengan konsepsi kepemimpinan profetik dalam Islam. Oleh karena itu, untuk membudayakan kepemimpinan transformatif di LPI, perlu didahului oleh penciptaan budaya organisasi yang mengimplementasikan nilai-nilai profetik. Kemudian untuk merealisasikannya dapat menggunakan tiga model pembudayaan, yaitu; model struktural, model formal dan model mekanik.
\end{abstract}

Kata Kunci: Kepemimpinan Profetik, Kepemimpinan Transformatif, Pembudayaan 


\section{Introduction}

Leadership is the key to the success of an organization including Islamic educational institutions. The success of the leader if viewed from the process perspective then the effectiveness in influencing members become its size. Leadership is the most important aspect of running an organization. ${ }^{1}$ Similarly, Islamic educational institutions, as an organization that has the function of organizing the process of Islamic education to internalize the Islamic teachings and values by Kaffah as a provision in living in the world and the afterlife. Leadership is different from leaders, leadership is a process, while leaders are individuals who explain the leadership process. The process is the process of influencing others to act effectively and efficiently to achieve a common goal.

Thus, the effectiveness of leadership becomes the benchmark of success in achieving objectives. Effective leadership is less concerned about the "technique " but more about character building. Leaders of today and the future will be focused on how to be and how to develop quality, character, mindset, values, principles, and courage. Strong leaders will be visionary, with the belief that they can and should shape the future. ${ }^{2}$

The word of leadership has a root word leader which means a person who has power or power to influence another person who is under his power to do something to achieve the goal. Leadership has different meanings if defined by different people. ${ }^{3}$ Researchers define leadership almost always based on individual perspectives and phenomena that draw their attention ${ }^{4}$ Leadership is defined as individual traits, behaviours, interaction patterns, role relationships, influences on groups, and places in administrative positions. However, the researchers expressly agree that the important element of leadership is a process rather than leadership as an individual.

Nevertheless, the average scientist agreed that the most important in the leadership was its effectiveness. Cultural, social, political and other differences will greatly influence the effectiveness of certain leadership styles. That is, the style or type of effective level of leadership depends on the variables that affect it.

The transformational leadership initiated by Bernard M. Bass is a theory of leadership that many people learn today. This is because leadership is considered an ideal

\footnotetext{
${ }^{1}$ Abuddin Nata, Manajemen Pendidikan: Mengatasi Kelemahan Pendidikan Islam Di Indonesia (Kencana, 2012), 7.

${ }^{2}$ David R. Kolzow, Leading From Within: Building Organizational Leadership Capacity, 2014, 310.

${ }^{3}$ Zaenal Arifin, "Efektifitas Kepemimpinan Lembaga Pendidikan Islam Di Pesantren," Jurnal Pemikiran Keislaman 27, no. 1 (January 5, 2016), https://doi.org/10.33367/tribakti.v27i1.258.

${ }^{4}$ Arifin.
} 
leadership to be applied in various conditions of society and organisation. However, it does not mean transformational leadership as the best leadership, sometimes, under certain conditions, other leadership types are also needed.

Therefore, this article aims to discuss how to cultivate transformational leadership in an Islamic educational institution (LPI). To discuss it, the author presents a little review related to the transformational leadership of Bernard M. Bass that is paired with transformational leadership from an Islamic perspective (in this case the prophetic leadership). Then continued by discussing some efforts made by Islamic educational institutions to cultivate the implementation of transformational leadership.

\section{Methods}

This article is the result of research by using the qualitative research method with a library approach. Data and data sources are derived from the literature search of both the book and the leading scientific journals. This study was conducted in June 2020 by involving a colleague from a team of Islamic education management lecturers.

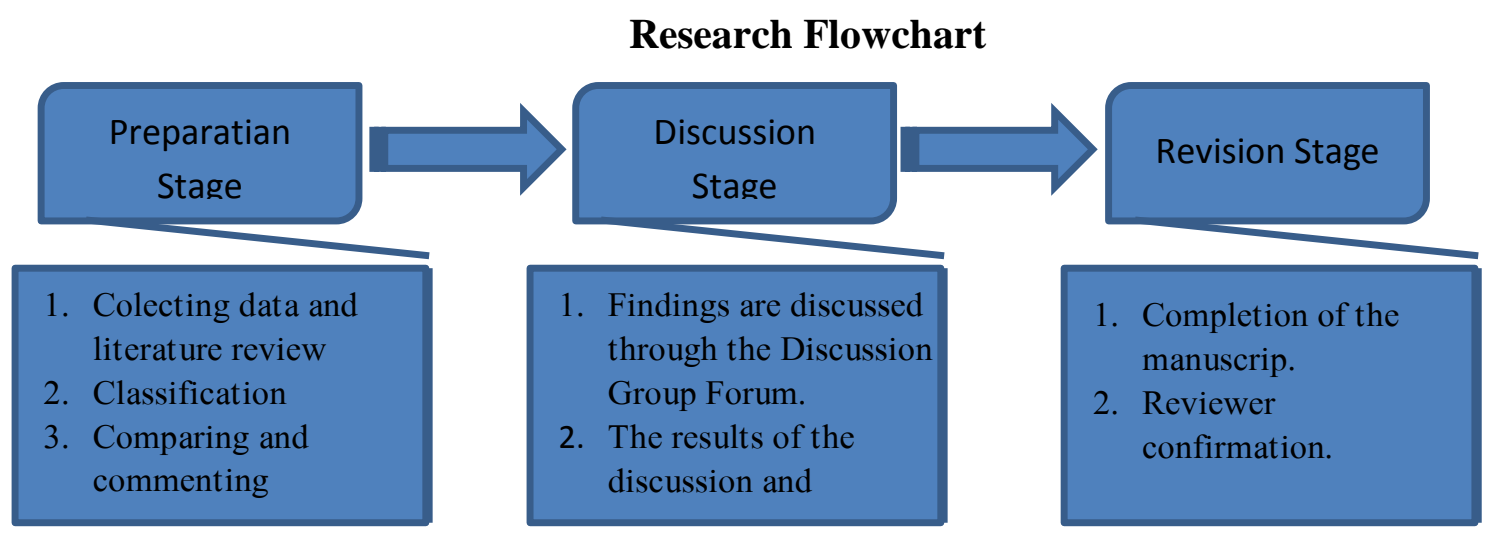

The process of drafting the manuscript is generally divided into 3 (three) stages. The preparation stage, discussion stage, and revision stage. The first stage uses the following steps. 1) data from the literature search results in the form of a scientific journal with the theme of transformative leadership and collected prophetic values that are developed and classified by the object and the focus of the study. 2) after the source and data classified according to the first step, the data is sorted based on the issuer's credibility and reputation, if it comes from the source of the scientific journal, then it is quite visible the accreditation level and its index. And 3) data that has been sorted is then analyzed by comparing and commenting on it.

The second stage is the discussion, this stage is done in the form of peer group by discussing the manuscript text both in terms of technical drafting and content and 
substance. The results of the discussion and various inputs were used as materials for revising manuscripts.

The third stage, revision of the manuscript. This stage is the completion stage of the manuscript based on discussion results and inputs. At this point, the confirmation is to share the text to given feedback to ensure that what is suggested is written according to the suggestion.

\section{Discussion}

\section{The Conception of Transformational Leadership}

The term transformational leadership was developed by Bernard M. Bass. Bass receives the view that leadership essentially does what the leader wants. Mentioned in his book, Bass and Stogdill's Handbook of Leadership (1990), Bass defines the leadership as "an interaction between two or more members of a group that often involves a structuring or restructuring of the situation and the perceptions and expectations of the Members". 5 A leader is a change agent, i.e. someone who acts to influence others more than the actions of others affect it. Leadership occurs when a group member changes the motivation or competence of others in a group.

In his other book with the title, "Leadership and Performance Beyond Expectation", Bernard M. Bass also likened the leadership to a leader who gained a "performance beyond what was expected" from his followers. This sense is taken by the statement: "To sum up, we see the transformational leader as one who motivates us to do more than we originally expected to do"6

Bernard M. Bass proposed that "to achieve follower performance beyond the ordinary limits, leadership must be transformational ". Superior leadership performance is transformational leadership. This happens when leaders expand and increase the interest of their employees, as they raise awareness and acceptance of group goals and missions, and when they direct their employees to see beyond their personal interests for the good of the group. ${ }^{7}$

\footnotetext{
${ }^{5}$ Bernard M. Bass, Ralph M. Stogdill, and Ralph M. Stogdill, Bass \& Stogdill's Handbook of Leadership: Theory, Research, and Managerial Applications, 3rd ed (New York: London: Free Press ; Collier Macmillan, 1990).

${ }^{6}$ Jon Pierce and John Newstrom, Leaders and the Leadership Process, 6 edition (New York: McGraw-Hill Education, 2010).

${ }^{7}$ Bernard M. Bass, "From Transactional to Transformational Leadership: Learning to Share the Vision," Organizational Dynamics 18, no. 3 (December 1990): 19-31, https://doi.org/10.1016/00902616(90)90061-S.
} 
According to the bass, the rate at which a transformational leader is measured primarily relates to the influence of leaders on the follower. Leaders change and motivate followers by: (1) To make them aware of the importance of assignment outcomes, (2) persuade them to exceed their personal interests for the sake of the organization or team, and (3) enable them to be at a higher level. According to Bass, transformational leadership can be achieved when implementing 4i (Idealized Influence, Inspirational Motivation, Intellectual Stimulation, Individual Consideration). As the chart below:

Chart 1. Theoritical Framework of Transformasional Leadership ${ }^{8}$

Dimension 1: Idealized Influence
Qualities of leader: risk-taker, ethical, and a role model
Dimension 2: Inspirational Motivation
Qualities of leader: enthusiastic, optimistic, motivator, and
provides challenges to others

Source: Bernard M Bass and Ronald E Riggio, Transformational Leadership (Mahwah, N.J.; London: Lawrence Erlbaum Associates, 2006).

First, Idealized Influence, this dimension refers to leaders who act as examples for their followers because of their remarkable ability and the doctrine of high ethical behaviour. ${ }^{9}$ Transformational leaders behave in a way that allows them to become role models for their followers and they are admired, respected, and trusted. Such leaders are regarded as icons because they show certain personal figures such as charisma. ${ }^{10}$ Idealized influences depict leaders acting as strong role models for their members. Leaders provide their members with a clear vision and mission for their company and, in turn, gain a high level of respect and confidence from its members.

\footnotetext{
${ }^{8}$ Bernard M Bass and Ronald E Riggio, Transformational Leadership (Mahwah, N.J.; London: Lawrence Erlbaum Associates, 2006).

${ }_{9}^{9}$ Bass and Riggio; Bruce J. Avolio and William L. Gardner, “Authentic Leadership Development: Getting to the Root of Positive Forms of Leadership," The Leadership Quarterly 16, no. 3 (June 2005): 315-38, https://doi.org/10.1016/j.leaqua.2005.03.001.

${ }^{10}$ Paul Kirkbride, "Developing Transformational Leaders: The Full Range Leadership Model in Action," Industrial and Commercial Training 38, no. 1 (January 2006): 23-32, https://doi.org/10.1108/00197850610646016; Bass and Riggio, Transformational Leadership.
} 
Second, Inspirational Motivation, this second component involves a leader's ability to motivate followers so that it can do beyond expectation ${ }^{11}$. Transformational leaders behave to motivate and inspire people around them by giving meaning and challenge to their follower work. ${ }^{12}$ Raising follower awareness about the mission and organizational vision, encouraging in every respect and making them committed to organizations is a key aspect of the transformational leadership of inspirational motivation. ${ }^{13}$

Third, Intellectual Stimulation; Intellectual stimulation essentially involves leaders that stimulate followers to think of problems and problems for themselves and thereby develop their abilities. Intellectual stimulation relates to the role of leaders to challenge creativity and innovation among the followers ${ }^{14}$. Followers are encouraged to try new approaches, and their ideas are not criticized because they are different from the leaders ' ideas. Intellectual stimulation arguably forms part of empowerment and ongoing improvement for followers or people.

Fourth, Individual Consideration; Transformational leaders pay special attention to the needs of each follower for achievement and growth by acting as a coach or mentor 15. Individual considerations are practised when new learning opportunities are created along with climate support and acknowledge differences between people in their strengths and weaknesses, likes and dislikes. Individual considerations are compressed with transformational leadership behaviours that leaders using this leadership style demonstrate consideration for their follower needs and are prepared to foster the development of appropriate workplace behaviour ${ }^{16}$.

The four transformational leadership components described above can be illustrated as shown in the chart below:

\footnotetext{
11 Priyanka Jain and Taranjeet Duggal, "Transformational Leadership, Organizational Commitment, Emotional Intelligence and Job Autonomy: Empirical Analysis on the Moderating and Mediating Variables," Management Research Review 41, no. 9 (September 17, 2018): 1033-46, https://doi.org/10.1108/MRR-01-2018-0029.

12 Bass and Riggio, Transformational Leadership.

13 Kirkbride, "Developing Transformational Leaders"; James C. Sarros and Joseph C. Santora, "The Transformational-transactional Leadership Model in Practice," Leadership \& Organization Development Journal 22, no. 8 (January 1, 2001): 383-94, https://doi.org/10.1108/01437730110410107.

${ }^{14}$ Ayman H. Metwally, Nada El-bishbishy, and Yehia Sabri Nawar, "The Impact of Transformational Leadership Style on Employee Satisfaction,” 2014.

15 Avolio and Gardner, "Authentic Leadership Development”; Bass and Riggio, Transformational Leadership.

16 Kirkbride, "Developing Transformational Leaders"; Sarros and Santora, "The Transformationaltransactional Leadership Model in Practice."
} 


\section{The components of transformational leadership}

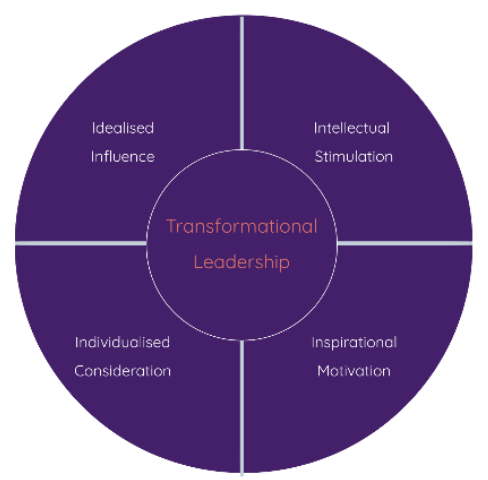

From the chart above, Bass explained more detail by giving some dimension of each component as the theoretical framework of transformational leadership. Four dimensions of transformational leadership must be owned by a transformational leader. Each one dimension reinforces the other dimension.

\section{The Conception of the Transformational Leadership of Islamic Perspectives}

In Islamic tradition, leadership has always been established on the leadership model of the Prophet Muhammad Saw and other prophets and companions of the Prophet Muhammad SAW. This is because the leadership in Islam as practised by the Prophet is the ideal model of leadership and always sourced in the Qur'an and Hadist which then conceptualized in the term prophetic leadership.

To interpret the leadership in Islam, the same is the same as how to inaugurated the concept of Khalifah mentioned in the Quran Sura al-Baqarah. The caliph was interpreted as a representative of God in charge of managing and maintaining balance on earth. Duties and khalīfah roles include enforcing the Lord's command, fair to all parties, have extensive knowledge and can cooperate with others. ${ }^{17}$ In a philosophical perspective, the caliphate was seen from human existence as a caliph, which is to carry out its function as a beneficiary to manage, organize, and utilize everything in the universe for the benefit of man itself. ${ }^{18}$ Also, it has the function of preserving nature from the destruction and the cause of human behaviour. This human existence manifests from the form of human devotion to God. That the Earth and the universe have a wide range of

\footnotetext{
17 Yesi Lisnawati, Aam Abdussalam, and Wahyu Wibisana, "Konsep Khalifah dalam al Quran dan Implikasinya terhadap Tujuan Pendidikan Islam; Studi maudu'i terhadap konsep Khalifah dalam Tafsir al Misbah," TARBAWY: Indonesian Journal of Islamic Education 2, no. 1 (May 5, 2015): 47-57, https://doi.org/10.17509/t.v2i1.3377.

${ }_{18}$ Zulhelmi Zulhelmi, "Konsep Khalifah Fil Ardhi Dalam Perspektif Filsafat (Kajian Eksistensi Manusia Sebagai Khalifah)," Intizar 24, no. 1 (2018): 37-54, https://doi.org/10.19109/intizar.v24i1.1879.
} 
potential that can be utilized for the sake of human life, including energy, so that humans are required to manage and utilize the existing energy sources well and minimize the damage that occurs as a result. ${ }^{19}$

Kuntowijoyo as the idea of prophetic social Sciences in his work entitled The New paradigm of Islamic Sciences: prophetic Social Sciences as an intellectual movement, mentions that Islam as an ideology that puts on the amar ma'ruf nahi munkar must be held the prophetic value of humanization, liberation, and Transendesi. ${ }^{20}$ First, humanization, the term is translated by Kuntowijoyo of the term Amar Ma'ruf which has the basic meaning of advocating or enforcing the policy, meaning that is intended to lift the human image and deliver to the Fitrah, namely the spirit of the divine. This conception departed from understanding that human beings are the position of man as God's noblest creature. $^{21}$

Second, liberalization is intended by Kuntowijoyo as the Spirit and foundation in implementing religious teachings, that religion is intended to liberate mankind from the oppressed. ${ }^{22}$ Although Kuntowijoyo made the concept of liberation in the context of science. ${ }^{23}$ But it can also apply in the context of running an organization or education management. In conducting education management, the spirit of change in society towards a better life based on the principle of liberation. ${ }^{24}$

Thirdly, transcendence is the spirit of religion that founded all the practices. ${ }^{25}$ The transcendence by Kuntowijoyo is taken from the fragment of the tu'minu billah verse which is the core of the two previous concepts (humanization and liberation). That the transcendence aspect is the main goal of every human activity and becomes the main terminal for the process of humanizing humanity and human liberation. ${ }^{26}$

The three concepts above are an integral part of the prophetic spirit that cannot be separated, must be viewed integrally, and become the foundation for the grounding of

\footnotetext{
${ }^{19}$ Muhammad Iqbal, "Mewujudkan Kesadaran Energi Melalui Konsep Khalifah Fi Al-'Ard," JURNAL PENELITIAN, June 28, 2016, 187, https://doi.org/10.28918/jupe.v13i2.1195.

${ }^{20}$ Kuntowijoyo, "Paradigma Baru Ilmu-Ilmu Islam: Ilmu Sosial Profetik Sebagai Gerakan Intelektual," Jurnal Mukaddimah V, no. 2 (1999).

21 Kuntowijoyo.

22 Kuntowijoyo.

${ }^{23}$ Maskur Maskur, "Ilmu Sosial Profetik Kuntowijoyo (Telaah atas Relasi Humanisasi, Liberasi dan Transendensi)" (masters, Universitas Islam Negeri Alauddin Makassar, 2012), 113, http://repositori.uinalauddin.ac.id/5754/.

24 Abdul Rahmat and Sruharini, Manajemen Profetik: Model Pemberdayaan Masyarakat Berbasis Pesantren Alam (Gorontalo: Ideas Publishing, 2018).

25 Maskur, "Ilmu Sosial Profetik Kuntowijoyo (Telaah atas Relasi Humanisasi, Liberasi dan Transendensi)," 115.

${ }^{26}$ Maskur, 117.
} 
Islamic values through the example of Prophet Muhammad SAW as the only human being who must be emulated by all Muslim societies in carrying out all their activities. For that reason, there are at least four characteristics that should be contextualized in carrying out formal education management activities specifically, namely; siddiq, amanah, tabligh, fathanah. $^{27}$

Table 1. Prophetic Values of Profetic Leadership ${ }^{28}$

\begin{tabular}{|l|l|l|l|l|}
\hline No. & \multicolumn{1}{|c|}{ Shiddîq } & \multicolumn{1}{c|}{ Amânah } & \multicolumn{1}{c|}{ Fathânah } & \multicolumn{1}{c|}{ Tablîgh } \\
\hline 1 & Integrity & $\begin{array}{l}\text { Responsibility for } \\
\text { his words }\end{array}$ & $\begin{array}{l}\text { Intelligent } \\
\text { intellectual }\end{array}$ & $\begin{array}{l}\text { Informative for } \\
\text { followers }\end{array}$ \\
\hline 2 & Fair, equitable & $\begin{array}{l}\text { Responsibility for } \\
\text { his actions }\end{array}$ & Intelligent emotional & $\begin{array}{l}\text { Eliminate } \\
\text { Immoral }\end{array}$ \\
\hline 3 & truthful & $\begin{array}{l}\text { Responsibility on } \\
\text { the task in hand }\end{array}$ & Intelligent Spiritual & $\begin{array}{l}\text { Accountable and } \\
\text { Transparent }\end{array}$ \\
\hline 4 & Loyal & Not cheating & $\begin{array}{l}\text { Can classify } \\
\text { Problems with the } \\
\text { following solutions }\end{array}$ & $\begin{array}{l}\text { Receive criticism } \\
\text { Constructive }\end{array}$ \\
\hline 6 & Improvements & $\begin{array}{l}\text { Granting rights } \\
\text { and legally } \\
\text { Fair }\end{array}$ & $\begin{array}{l}\text { Able to compile } \\
\text { Plans and strategies } \\
\text { Appropriate } \\
\text { resources }\end{array}$ & Innovative and \\
creative & Communicative \\
\hline 7 & Model & $\begin{array}{l}\text { Honor and } \\
\text { confidence }\end{array}$ & Ethics & Motivation \\
\hline 8 & & & Reason & Relationship \\
\hline 9 & & & & Empathy \\
\hline
\end{tabular}

The table above illustrates that the leadership is based on prophetic values in line with transformational leadership, and can even according to the author's frugal can be beyond. This is because the spirit of transcendence that lubricated prophetic leadership is not present in the transformational leadership.

First, Siddiq (honest). The nature of honesty is a great asset for a transformational leader because the essence of leadership is trusted. After all, it is impossible to lead people who do not believe in your leadership. ${ }^{29}$ Subordinates find it difficult to trust a leader who is not honest. Honest leaders have characters with integrity, fairness, loyalty, and objectivity. Second, Amânah (trust). Amânah has the meaning of being responsible for

${ }^{27}$ Agam Hyansantang Maulana, Imron Arifin, and Raden Bambang Sumarsono, "Kepemimpinan Profetik Islam Oleh Kepala Madrasah," JAMP : Jurnal Administrasi Dan Manajemen Pendidikan 2, no. 1 (January 22, 2019): 26-31.

28 Indah Kusuma Dewi, "Implementasi Nilai-Nilai Profetik Dalam Kepemimpinan Modern Pada Manajemen Kinerja Di Perguruan Tinggi Islam Swasta Kota Metro” (PhD, Pascasarjana Doctor, 2019), 51, http://repository.radenintan.ac.id.

${ }^{29}$ Stephen P. Robbins and Tim Judge, Organizational Behavior, 15th ed (Boston: Pearson, 2013), 200. 
words and deeds. A leader who has a trustworthy nature always has the principle of being accountable, misuse of the trust results in a corrupt nature. Third, fathanah (intelligent). in the perspective of multiple intelligent, intelligence has a broad meaning, all the advantages of an individual are intelligence. Every human being is equipped with intelligence, but intelligence needs to be developed. A leader is required to be able to develop his intelligence, especially intellectual intelligence and social intelligence. And fourth, tabligh (informative). A leader must be informative towards subordinates. Each program must be well conveyed to subordinates.

\section{Efforts to Cultivate Transformational Leadership in Islamic Education Institutions}

Transformational leadership can be pursued through 4 (four) components or dimensions in it. When outlined, the leadership of the LPI should act with 4 components, namely: First, Idealized Influence, the leader is seen by the subordinates as the figure of the example, Uswah, and figure that is considered capable of providing the best policy for the Madrasah. Second, Inspirational Motivation, the leader of LPI inspires and supports members to cooperate in realizing the purpose of the institution in particular and the purpose of all components of the institution in general. Thirdly, Intellectual Stimulation, the leadership of LPI provides the breadth of opportunities for its members to create and think critically for the progress of the Madrasah. And fourth Individual Consideration, the leader of the LPI is individually trusted as a place to consult all polemic, even he can act as the trainer of the members and advise them to support a better education process.

When examined carefully, it is understood how the bottom-up concept is felt by implementing transformational leadership in the LPI. Even Northouse who also quoted Daryanto stated that it becomes a special advantage if the institution has a leader who can apply transformational leadership because the effectiveness of the process and the outcome of work is very perceived significant development by the institution itself. ${ }^{30}$

Islamic Educational institutions in Indonesia has a large capital to cultivate transformational leadership. Among the first capital is the transcendental capital, the transcendence is the spirit of religion that lubricated all practices. ${ }^{31}$ The transcendence by Kuntowijoyo taken from the passage tu'minu billah is the main goal of every humanitarian

\footnotetext{
${ }^{30}$ Daryanto, Kepala Sekolah Sebagai Pemimpin Pembelajaran (Yogyakarta: Gava Media, 2011), 146.

31 Maskur, "Ilmu Sosial Profetik Kuntowijoyo (Telaah atas Relasi Humanisasi, Liberasi dan Transendensi)," 115.
} 
activity. ${ }^{32}$ With this capital, leadership will avoid the orientation of worldly gains. Therefore, in turn, it carries on the behaviour of corrupt, collusion, and nepotism.

\section{Transformational leadership expectations}

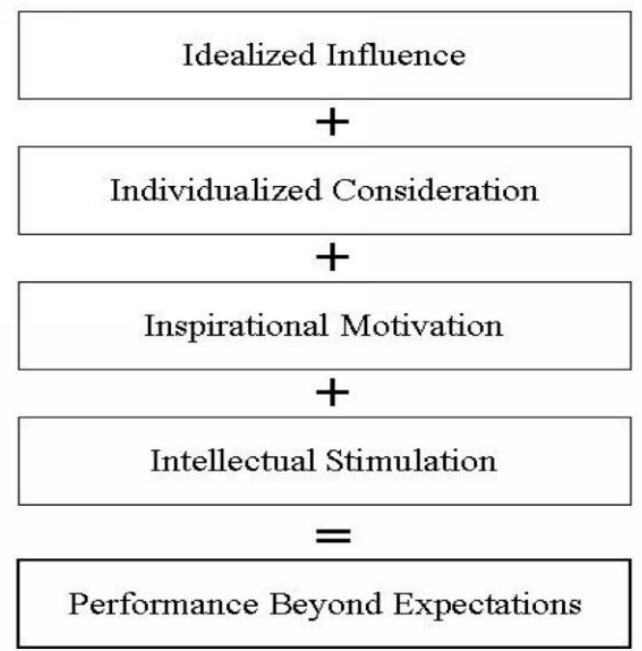

The picture above explains that to obtain performance results outside the expectations of a leader must apply $4 \mathrm{i}$, cannot be partial or half, $4 \mathrm{i}$ must be implemented in totality. The transformative leadership position in an educational institution is on the whole organization/institution. Therefore, the culture of transformation will not be achieved without the implementation of the overall transformative values by an organization/institution. Nevertheless, the leader's position remains the spearhead of the implementation of Transformation leadership. Not to mention if it is associated with the existence of LPI in Indonesia, where the diversification of LPI in Indonesia and diversification will only lead to duplication, useless and ineffectiveness if the term only means pseudo-diversified with the purpose of outside and artificial. ${ }^{33}$

In general, culture can be formed through prescriptive and also through programs as learning process or solutions to certain problems. To cultivate transformational leadership in an educational institution it takes what is called a model of culture. The Model of culture is usually considered correct, but also conditional. Thus, the modelling of transformational leadership is strongly influenced by situations and conditions in which the model will be applied along with the application of underlying values. There are at least 3 (three) models to foster a culture of transformational leadership in LPI, ie; Structural models, formal models and mechanical models.

\footnotetext{
32 Maskur, 117.

${ }^{33}$ Binti Maunah, "Lembaga Pendidikan Islam Di Indonesia: Kajian Deskripsi-Analitik Model Lembaga Pendidilan Islam,” Empirisma: Jurnal Pemikiran Dan Kebudayaan Islam 24, no. 2 (July 1, 2015), https://doi.org/10.30762/empirisma.v24i2.23.
} 
First, the structural model, the leadership if viewed from the perspective of sociology theory is a social fact immaterial that can be created by certain community groups. Similarly, the transformative leadership that can start from the creation of the atmosphere is accompanied by the planting of prophetic transformative values in Istiqamah. This Model of cultured is done by creating a culture of the organization that is encouraged by the existence of regulations, the development of impressions, both from the outside world of the leadership or policy of an institution or an organization. This Model is usually "top-down", that is, through policies made on initiatives or instructions from officials or leaders. Also, the creation of media and facilities and infrastructure that supports the culture of transformative leadership should be provided.

Secondly, the Formal Model, the culture of transformative leadership using Formal models is done by instilling a spirit of confidence in human life after death. That is, here religious teachings have an important role. That true human life is life after death, and living in the world is a stage that must be passed by man to seek provision for life after death. While The provision is in the form of religious orders and leaves religious restrictions. As in the concept of religious teaching (Islam), what human beings have in the world is God's mandate that must be managed well, including the organization/LPI.

Third, mechanical Model. The culture of transformative leadership through a mechanical model is done by creating awareness and understanding that life consists of various aspects; and organizations/institutions is an educational process that is viewed as planting and developing a set of life values, each of which moves and operates according to its function. Every movement is like a machine consisting of several components, where each component performs its functions and can consult one another or cannot be consulted.

\section{Conclusion}

The characteristics and objectives of transformational leadership are in line with the conception of prophetic leadership in Islam. Therefore, to cultivate transformative leadership in the LPI, it needs to be preceded by the creation of an organizational culture that implements prophetic values. Then to be able to use three models of cultures, namely; Structural models, formal models and mechanical models. 


\section{References}

Arifin, Zaenal. "Efektifitas Kepemimpinan Lembaga Pendidikan Islam Di Pesantren." Jurnal Pemikiran Keislaman 27, no. 1 (January 5, 2016). https://doi.org/10.33367/tribakti.v27i1.258.

Avolio, Bruce J., and William L. Gardner. "Authentic Leadership Development: Getting to the Root of Positive Forms of Leadership." The Leadership Quarterly 16, no. 3 (June 2005): 315-38. https://doi.org/10.1016/j.leaqua.2005.03.001.

Bass, Bernard M. "From Transactional to Transformational Leadership: Learning to Share the Vision." Organizational Dynamics 18, no. 3 (December 1990): 19-31. https://doi.org/10.1016/0090-2616(90)90061-S.

Bass, Bernard M, and Ronald E Riggio. Transformational Leadership. Mahwah, N.J.; London: Lawrence Erlbaum Associates, 2006.

Bass, Bernard M., Ralph M. Stogdill, and Ralph M. Stogdill. Bass \& Stogdill's Handbook of Leadership: Theory, Research, and Managerial Applications. 3rd ed. New York : London: Free Press ; Collier Macmillan, 1990.

Daryanto. Kepala Sekolah Sebagai Pemimpin Pembelajaran. Yogyakarta: Gava Media, 2011.

David R. Kolzow. Leading From Within: Building Organizational Leadership Capacity, 2014.

Indah Kusuma Dewi. "Implementasi Nilai-Nilai Profetik Dalam Kepemimpinan Modern Pada Manajemen Kinerja Di Perguruan Tinggi Islam Swasta Kota Metro.” PhD, Pascasarjana Doctor, 2019. http://repository.radenintan.ac.id.

Iqbal, Muhammad. "Mewujudkan Kesadaran Energi Melalui Konsep Khalifah Fi Al'Ard." JURNAL PENELITIAN, June 28, 2016, 187. https://doi.org/10.28918/jupe.v13i2.1195.

Jain, Priyanka, and Taranjeet Duggal. "Transformational Leadership, Organizational Commitment, Emotional Intelligence and Job Autonomy: Empirical Analysis on the Moderating and Mediating Variables." Management Research Review 41, no. 9 (September 17, 2018): 1033-46. https://doi.org/10.1108/MRR-01-2018-0029.

Kirkbride, Paul. "Developing Transformational Leaders: The Full Range Leadership Model in Action." Industrial and Commercial Training 38, no. 1 (January 2006): 23-32. https://doi.org/10.1108/00197850610646016.

Kuntowijoyo. "Paradigma Baru Ilmu-Ilmu Islam: Ilmu Sosial Profetik Sebagai Gerakan Intelektual." Jurnal Mukaddimah V, no. 2 (1999).

Lisnawati, Yesi, Aam Abdussalam, and Wahyu Wibisana. "Konsep Khalifah dalam al Quran dan Implikasinya terhadap Tujuan Pendidikan Islam; Studi maudu'i terhadap konsep Khalifah dalam Tafsir al Misbah." TARBAWY: Indonesian Journal of Islamic Education 2, no. 1 (May 5, 2015): 47-57. https://doi.org/10.17509/t.v2i1.3377.

Maskur, Maskur. "Ilmu Sosial Profetik Kuntowijoyo (Telaah atas Relasi Humanisasi, Liberasi dan Transendensi)." Masters, Universitas Islam Negeri Alauddin Makassar, 2012. http://repositori.uin-alauddin.ac.id/5754/. 
Maulana, Agam Hyansantang, Imron Arifin, and Raden Bambang Sumarsono. "Kepemimpinan Profetik Islam Oleh Kepala Madrasah." JAMP: Jurnal Administrasi Dan Manajemen Pendidikan 2, no. 1 (January 22, 2019): 26-31.

Maunah, Binti. "Lembaga Pendidikan Islam Di Indonesia: Kajian Deskripsi-Analitik Model Lembaga Pendidilan Islam." Empirisma: Jurnal Pemikiran Dan Kebudayaan Islam 24, no. 2 (July 1, 2015). https://doi.org/10.30762/empirisma.v24i2.23.

Metwally, Ayman H., Nada El-bishbishy, and Yehia Sabri Nawar. "The Impact of Transformational Leadership Style on Employee Satisfaction,” 2014.

Nata, Abuddin. Manajemen Pendidikan: Mengatasi Kelemahan Pendidikan Islam Di Indonesia. Kencana, 2012.

Pierce, Jon, and John Newstrom. Leaders and the Leadership Process. 6 edition. New York: McGraw-Hill Education, 2010.

Rahmat, Abdul, and Sruharini. Manajemen Profetik: Model Pemberdayaan Masyarakat Berbasis Pesantren Alam. Gorontalo: Ideas Publishing, 2018.

Robbins, Stephen P., and Tim Judge. Organizational Behavior. 15th ed. Boston: Pearson, 2013.

Sarros, James C., and Joseph C. Santora. "The Transformational-transactional Leadership Model in Practice." Leadership \& Organization Development Journal 22, no. 8 (January 1, 2001): 383-94. https://doi.org/10.1108/01437730110410107.

Zulhelmi, Zulhelmi. "Konsep Khalifah Fil Ardhi Dalam Perspektif Filsafat (Kajian Eksistensi Manusia Sebagai Khalifah)." Intizar 24, no. 1 (2018): 37-54. https://doi.org/10.19109/intizar.v24i1.1879. 